\title{
AN EXPERIMENTAL STUDY ON THE EFFECT OF PARTS STRATEGY AND ANXIETY ON READING COMPETENCY AT THE ELEVENTH GRADE STUDENTS OF SMAN 5 DENPASAR
}

\author{
Lindawati, $\mathrm{P}$. \\ Language Education Department, Post-Graduate Program \\ Ganesha University of Education \\ Singaraja, Indonesia \\ e-mail:putu.lindawati@pasca.undiksha.ac.id \\ Tantra, D. K. \\ Language Education Department, Post-Graduate Program \\ Ganesha University of Education \\ Singaraja, Indonesia \\ e-mail:komang.tantra@pasca.undiksha.ac.id \\ Ratminingsih, M. \\ Language Education Department, Post-Graduate Program \\ Ganesha University of Education \\ Singaraja, Indonesia \\ e-mail: made.ratminingsih@pasca.undiksha.ac.id
}

\begin{abstract}
The aim of this study was to prove whether the implementation of PARTS Strategy and the students' anxiety gave a significant effect to the students' reading competency. The study was an experimental study by applying Post test only control group design. The population was nine classes (420 students) of grade XI in SMA Negeri 5 Denpasar academic year 2012/2013, in which 2 classes were samples which were assigned into two groups, i.e. experimental group and control group, by a Multi-Stage Random Sampling. The research data were collected through questionnaire and test that were analyzed using Statistical Two-Way Anova. The results show that, first, there was different effect in reading competency between the students who were taught by implementing PARTS strategy and those who were taught by implementing Conventional reading startegy (Sig. $=0.004<\alpha=0.05$ ). Secondly, there was not interactional effect of PARTS strategy and anxiety level upon the students' reading competency at the eleventh grade students of SMA negeri 5 Denpasar (Sig. $=0.966>\alpha=0.05)$. In view of the results of this study, it is therefore suggested that teachers should use PARTS Strategy as an innovative teaching strategy since the facilitation of this strategy significantly improved the students' reading competency.
\end{abstract}

Keywords : PARTS Strategy, Anxiety, Reading Competency

\section{INTRODUCTION}

Reading can be placed in the first place of the most important skill in learning English. Some researchers believed that reading could support the process of mastering the other skills and improving the knowledge. However, the fact shows that not every individual learns it well. Moreover, in Indonesia, English is a foreign language. Thus, the way how the students in comprehending reading skill is totally different with the native students.

Williams, (2010) wrote in her article that there are three minds of major problems in reading comprehension that being faced by students. First is language problem. Language plays a vital role in the reading skill. It can be taken an analogy like in ice hockey game. Someone who cannot skate will not able to play the ice hockey game. Thus, if someone has poor knowledge in English, his reading will also be poor and naturally also his reading comprehension. Second is foundational skill of reading haven't been atomized. It can be taken a case in speaking. When someone attempted to speak with a language which hasn't become automatic yet, necessarily he will try to divide his attention into two, contain of the text and the language itself. Because of his divided attention, the way how he 
speaks will be haltingly and with great difficulty. It also happened in reading skill, when the foundational skill of reading hasn't become automatic yet; the person will read haltingly and has great difficulty. The poor or lower level reader will try to force himself to apply his concentration to the word recognition and therefore has "no concentration left" to decode the written words. Finally, as the result, he will not be able to read with comprehension. The last problem is word recognition problem. The ability in decoding or recognizing the written words is very important. It is very impossible to get maximum reading comprehension without able to decode or recognize written words. Grabe (2004) cited in Chang (2010) stated that automatic word - decoding skills and prior knowledge of a text's content may interact and strongly affect success in comprehension. When learners are exposed to a large quantity of varying texts, their topical knowledge may be enhanced. This can explain why someone can "read" without understanding what they are reading.

Moreover, if we relate reading to the curriculum, reading has two competencies that should be achieved by students. Those are standard competency and basic competency. The standard competency of reading is the general competency that should be achieved by students while basic competency is the minimum competency that should be achieved by students in learning certain subject. The basic competency of reading skill as mentioned in the school based curriculum, especially in the eleventh grade students of senior high school is comprehending functional text leading to varieties of interpersonal meaning and/or oral monologue in the form of recount and narrative text. The achievement indicator is that the students must be competent in sub reading skills that involve comprehending main idea, specific information, word meaning, and textual references of the text. It means that the learning process should be emphasized on the implementation of reading skill, without ignoring the other skills, like listening, speaking and writing.

In other words, If the student has the potential to learn, if his general and school experiences combine appropriately with his need to learn then he should progress a long a continuum toward ever increasing reading maturity. The purposeful reading interpretation involves the selective and flexible derivation of the larger and deeper meaning conveyed by the writer's message. Reading purpose, well defined in terms of needed interpretation and reaction responses, aids reader set. Such a purpose may be shaped by teacher direction or self determined by the reader's interest in the topic and conception of the reading task. If the purpose is internalized by the reader, and if it is readily attained through reading the selection, it usually produces better interpretation of the content. This seems to hold not only for that meaning which is most pertinent to the given purposes but also to relate content meaning.

In fact, even though the teaching of reading has been developed since grade seven of junior high school, students still face difficulties in achieving the reading skill, not all the competencies stated on the curriculum achieved well by the students. Base on the researcher's previous observation at SMA Negeri 5 Denpasar, it was still found that the students commonly encountered a lot of difficulties in finding out the main idea, the specific information, textual reference, and the word meaning of the text. Besides, the students also got difficulties in answering the comprehension questions about the content of the text. The researcher had also identified that the problem was caused by the teacher's teaching strategy. The students said that when they have reading class, the teacher just asked them to read the test, and then answering some questions related to the content of the text. When the students finished answering those questions, the teacher assumed that students have understood and comprehended the text; it was done monotonously, and could make the students become less motivated in reading class.

Moreover, the result of the informal interview with the students showed that the students of eleventh grade in SMA Negeri 5 Denpasar got difficulty in following the reading class. The problem was caused by several factors. The first factor was the students' lack vocabulary. It made the students just read the passage without understanding it wholly. Besides, the students stated that they only have limited number of vocabulary so that they become easily to get bored when they read a text. The second factor was the students' lack knowledge about the topic. They rarely had good background knowledge relate to the topic in the text that they were going to read. The students said that the rarely have any idea related to the text before they read the passage since the teacher seldom gave prequestions related to the text. This caused them difficult to understand the text.

The researcher had also identified that the problem was caused by the teacher's inappropriate strategy. Conventional reading technique often failed to improve students' reading competency. Many students 
said the teacher rarely asked pre-questions related to the text that they were going to read so that their prior knowledge was not truly activated when they read a text. Moreover, the teacher only asked the students to read the text and then asked them to answer the questions. When the students have finished answering the questions, the teacher assumed that the students had already understood the content of the passage. This was monotonous way of teaching reading so that the students become less motivated in reading class.

All of those problems above made the students inactive and unenthusiastic in following the class. As the result, the students got low score in reading comprehension; it was proved by the result of the students weekly examination test in reading competency. It was found that the achievement of the students in reading comprehension was 53.71 which categorized as "insufficient", and finally will affect the students' achievement in reading competency. In line with this phenomenon, it is important to take an innovative teaching strategy into consideration in order to solve the problem and to improve the students' competency in reading comprehension. The innovative strategy that the teacher uses in teaching will greatly influence the students' competency. The teacher should be aware of the strategy that is used, in order to make the students easy to comprehend the reading text. In teaching reading, the teacher is not only assigning paper to be read, taught, asked questions, but the teacher has to check whether or not the students have better understanding about the main idea, specific information, word meaning, and textual reference of the text.

Nowadays, many kinds of strategy for teaching reading have been applied by some researchers to help the students to improve their competency in reading comprehension. However, most of the techniques were still less effective and communicative because in the real situation, most of the students still have difficulties in reading comprehension. Furthermore, Rainey in Juniari (2010) proposed PARTS Strategy as an effective and communicative strategy to be applied in teaching reading comprehension. This strategy stands for Preview, Anticipation, and Read, Think critically and summarize. This strategy is based on the strategies that most good readers use when they are reading. This strategy is related to some technique that help the reader to enjoy their reading, and to help them read quickly but still remember the main points of the text.

Furthermore, Januari (2005) has proved the effectiveness of PARTS Strategy. She applied this strategy at SMAN 4 Singaraja in the Social Science Class in order to improve the students' achievement in reading comprehension especially in finding out the main idea, specific information, textual reference and word meaning. By this strategy the students could develop their understanding about a text since they had to be active in following all the steps in Parts Strategy.

In other words, it is widely believed that learning of any kind takes place best in pleasant surroundings by persons with a positive attitude. It's not only external factors that can influence the students' achievement in the classroom but also internal factors which are known as affective domain. This would be lead students to believe that stress, anxiety would make learning process very difficult. Some students learn more quickly and easily that other students. Generally, the affective domain describes the way people react emotionally and their ability to feel another living thing's pain or joy (Suzanne Graham 2000). Affective domain refers to those actions that result from and are influenced by emotion, and feelings. Consequently, the affective domain related to emotions, attitudes, appreciations and values. It is highly personal to learning, demonstrated by behaviors indicating attitude of interest, attention, concern, and responsibility. In the classroom, the affective domain is concerned with students' perception of the subject which they are learning, their feelings toward solving problem, and their attitudes about school and education in general. Personal development, self management, and the ability to focus is the key.

Anxiety is one of the affective factors, which are generally assumed to influence the students' achievement especially in reading competency. According to Martin (2007) anxiety is the fear of unknown. It is a very natural physiological response of the body, when we face challenges, especially the challenges that we have never endured. In relation to reading, the students' anxiety may be caused by several factors such as new theory, do not understand the explanation which is explained by teacher, or do not know what to do. In line with this, Zeidner (1998) says that anxiety is not an exclusive event. Students worried about theory, behavioral, and emotional responses that lead to academic achievement is not comparable with the ability to learn and lead to failure in learning and evaluation situations. Behaviors such as anxiety lead a person to avoid task, avoid themselves, refuse to handle and anxiety in creating a task, low academic self-concept, low self-esteem, high doubt, no 
concentration, confusion level is high and others. The anxiety of students may in form of high anxiety and low anxiety.

Both high and low anxiety will influence students' reading competency. The students who have a higher scale of anxiety have an effect on their achievement, that is lower achievement than students who have lower scale of anxiety (Marhaeni, 2007). It finds that students with low anxiety have senses of each anxiety dimensions (tension, worry, weary, nervousness, affraidness, and restlessness) but not too interfere with learning. Conversely, the students with categorize high anxiety have senses of each of anxiety dimensions (tension, worry, weary, nervousness, affraidness, and restlessness) than can sometimes interfere with learning. Because the students feel worry then they read certain text that will influence their reading competency.

The relationship between anxiety and academic performance has been studied in a variety of laboratory and natural setting. Individuals experiencing anxiety show apprehensions that often interfere with performance in everyday life as well as in academic situations. Anxiety in general is expected to have a negative effect on students' performance and achievement. One consistent findings shows that individuals who have high level of anxiety performs less well that those who have low anxiety on evaluation or ego threatening tasks (Vogel \& Collins, 2000). The way students perceive and experience their academic related matters is also one of the factors that could affect the performance and achievement of the students. For instance, according to Vogel and Collins (2000), if individual's experience of previous achievement is negative, then the anxiety level is higher and this leads to lower performance. Consequently, if the experience is positive, then the anxiety level is lower and this leads to a higher performance. A study about anxiety was conducted by Seligment and Wuyek (2007). They found that highly anxious students were significantly more likely to score lower on measure of academic achievement and peer acceptance. Longitudinal analysis revealed that high anxious students, compared to their low anxious peers, scored significantly lower on measure of academic achievement, aggression, and peer acceptance.

The study above showed that anxiety can directly influence the students' academic achievement. It was reported that anxiety could affect students' academic achievement in the sense that students with high anxiety level perform poorer compared to those with low anxiety. Moreover learning an additional language is both cognitively and emotionally demanding (Abu-Rabia, 2004). Anxiety, a complicated phenomenon is a kind of emotion so the issue of anxiety in second language (L2) learning has concerned language educators and researchers for many years. A substantial amount of research has been conducted in this area and suggests that anxiety is an important factor in second language acquisition (Na, 2007; Wei, 2007). However, most of the research centers on the discussion of listening, speaking and writing. Little attention has been paid to reading. Thus, the present study will propose this study to find out the effect of PARTS Strategy and Students' anxiety on reading competency at the eleventh grade students of SMA Negeri 5 Denpasar.

Generally, understanding and analyzing students' reading problems and solution to the problems encountered by students in reading competency at the eleventh grade students of SMAN 5 Denpasar. Specifically, Analyzing the main and international effects of PARTS strategy and anxiety level upon the students' reading competency at the eleventh grade students of SMAN 5 Denpasar.

\section{RESEARCH METHODOLOGY}

This study was an experimental research, Fraenkel and Wallen (2006) state that the basic idea underlying all experimental research is really quite simple; try something and systematically observe on what happens. The purpose of this research is to find out the effect of the implementation of PARTS strategy and students' anxiety on reading competency between two classes which will be taught with different technique of PARTS strategy and Conventional reading technique by manipulating the independent variables; PARTS Strategy and anxiety level, whereas the other variables cannot be definitely controlled

This present study was Quasy Experimental research. The design of this study was Posttest-Only Control Group Design. Population is a group of individuals which have one or more characteristics. It is the group of interest to the researcher, the group to whom the researcher would like to generalize the results of a study (Fraenkel and Wallen, 2006). The term of population used in research refers to all members of a particular group. In this study, the eleventh year students of SMAN 5 Denpasar in the academic year 2012/2013 was taken as the population. There are 9 classes of eleventh grade 
students in SMAN 5 Denpasar which all together consist of 420 students. The students of both classes were joined the treatment and was taught by implementing different technique. At the end of the treatment, a posttest will be administered and the score of both groups were analyzed to attest of statistical significant. The posttest was expected to give information about the effect of the treatment towards students' reading competency and their anxiety level. The technique of sampling that the researcher used is a Multi-Stage Random Sampling which that totally 92 students were the sample of the research, By given lottery, researcher decided the one class for control group and one class for experimental group that was class XI.2 as an experimental group (46 students) and class XI.5 as a control group (46 students). It means that totally 92 students were the sample of the research.

The data were analyzed by using descriptive statistic analysis and inferential statistic analysis. The descriptive statistic analysis was conducted to obtain the mean score and the standard deviation of the two groups. Meanwhile the inferential statistic analysis was done by using two ways ANOVA and Tukey test if there is any interaction between PARTS Strategy and students' anxiety level. before the test was analyzed, the normal distribution and the homogeneity of the variance need to be analyzed.

\section{FINDINGS AND DISCUSSION}

First, The result of hyphotesis testing has rejected null hyphotesis ( $\mathrm{H} 0)$ which states there is no significant different effect on students' reading competency between the students who were taught by PARTS strategy and those who were taught by conventional reading strategy, or receiving alternativehyphotesis $(\mathrm{H} 1)$ which states that there is significant different effect on students' reading competency between the students who were taught by using PARTS strategy and those who were taught by using Conventional reading strategy. It based on the result of the calculation in which Sig.< $(0.004<0.05)$, so it can be concluded that there is significant different effect on students' reading competency between the students who were taught by PARTS strategy and those who were taught by conventional reading strategy. The mean score of students' reading competency taught by PARTS strategy ( $\mathrm{A} 1=23.43$ ) was higher than the mean score of the studnts' reading competency who were taught by conventional reading strategy ( $\mathrm{A} 2=18.89$ ).

The first result of data analysis discovered that PARTS strategy affected better than conventional reading straegy. In this research, PARTS strategy was the treatment given to the experimental group. PARTS strategy was considered as an effective and innovative strategy to reading that enable students to improve their reading competency.

There were some reasons of why PARTS strategy was better than conventional reading strategy. This strategy was related to some techniques that usually help the students not only to enjoy their reading but also to read quickly and remember the main points of the text wholly.

In the preview step, the students tried to see the text in general from the title, pictures, graphs, and the author's name. The students also read the first sentence of each paragraph. This activity help the students prepared their mind to accept the information in reading text. Moreover, in anticipate, the students tried to guess and anticipate what the reading text will be about. The purpose of this step was to focus the students' attention on the reading. Anticipating help them stay interested and to stay awake.

Read and reread step divided into two parts. The first was the students read the text silently and quickly, marked any unfamiliar words but did not stop finding the meaning of the words. This was done because interrupting yourself caused you to lose track of the main ideas. The second parties, the readers reread the text more slowly, find the meaning of unknown words and mark the important points to maximize their understanding and led them to understand and comprehend the content of the text well.

In the think critically, the students thought the message expressed in the text, and expressed their own reaction and comment to the reading. In relation to this, Mayers (1986:27) affirms that the students ability in using their experience to give comments and reactions can strengthen their critical thinking.

In the summarize step, the students marked points in the reading and made a summary of the important points of the text. In this step when the students had been able to make the good summary of the text, it meant that the students had understood and comprehended the main point and the content of the text wholly. 
Therefore, PARTS strategy gave many advantages to the students, such as help the students understand and remember what they had read, help the students focus on the organizing information in their mind and making it meaningful. this strategy was effective in improving students' understanding and memory for key ideas of the information of printed materials, this strategy was easy to use and can be applied in most academic subject. PARTS strategy help the students for better comprehend of written material.

Compared to Conventional reading strategy, the students' reading comprehension was lower because in this strategy the teacher just asked the students to read the test, and then answering some questions related to the content of the text. When the students finished answering those questions, the teacher assumed that students have understood and comprehended the text; it was done monotonously, and could make the students become less motivated in reading class then feel anxious because they were not interested with the subject taught. Thus, it can be concluded that PARTS Strategy was an effective and innovative strategy in improving the students' reading comprehension.

The result above is supported by the findings which is got by Juniari (2005), it was conducted to the second year students of social science of SMAN 4 Singaraja in the academic year 2005/2006. When using this strategy, she found that the students got better result on reading competency and were interested and gave positive response toward the application of PARTS strategy in reading class.

Second, The result of hyphotesis testing has rejected $\mathrm{H} 1$ which states that there is a significant interactional effect between PARTS strategy and anxiety on students' reading competency, or receiving null hyphotesis (H0) which states there is no a significant interactional effect between PARTS strategy and anxiety on students' reading competency. It based on the result of the calculaton in which Sig.> $(0.966>0.05)$, so it can be concluded that there is no significant interactional effect between PARTS strategy and anxiety on students' reading competency. Thus, students with low and high anxiety scale had better reading competency when they were taught by using PARTS strategy than taught by using conventional reading strategy.

Furthermore, the teaching strategy has an important role in determining the students' anxiety level. For the students who have high anxiety taught by using an effective and innovative teaching strategy, it can decrease their level of anxiety because they are interested and motivated in learning the subject taught. And also for the students who have low anxiety, they can keep motivating and give more positive reactions and responses toward the subject taught by the teachers and affect to their achievement. Thus, PARTS strategy can be one of an effective and innovative teaching strategy in improving the students achievement in their reading comprehension rather than conventional reading stratgey.

The result above supported by Newstead (2004) which states that the teachers' learning strategy determined the students achievement, if the teachers were not able to apply an innovative strategy and less motivated it will make the students bored, not interested then finnaly make them feel anxious and affect to their learning achievement.

In conclusion, PARTS strategy as and effective and innovative teaching strategy gave positive effect for low and high anxiety students. It means that both high and low anxiety, students had higher scores in PARTS strategy, while both high and low anxiety, students had lower score in conventional reading strategy. Thus, PARTS strategy was an effcetive strategy in improving students' reading comprehension regardless of anxiety level.

\section{CONCLUSION AND SUGGESTION}

Based on the result of data analysis and discussion, it can be drawn several conclusions that can be presentedas follows:

There is significant different effect on students' reading competency between the students who were taught by using PARTS strategy and those who were taught by using Conventional reading strategy. It based on the result of the calculation in which Sig. $<(0.004<0.05)$, so it can be concluded that there is significant different effect on students' reading competency between the students who were taught by PARTS strategy and those who were taught by conventional reading strategy. The mean score of students' reading competency taught by PARTS strategy $(\mathrm{A} 1=23.43)$ was higher than the mean score of the studnts' reading competency who were taught by conventional reading strategy $(\mathrm{A} 2=18.89)$. 
There is no a significant interactional effect between PARTS strategy and anxiety on stduents' reading competency. It based on the result of the calculaton in which sig. $>(0.966>0.05)$, so it can be concluded that there is no significant interactional effect between PARTS strategy ans anxiety on students' reading competency.

It is research for the english teacher of grade XI in SMAN 5 Denpasar to use PARTS strategy as an alternative and effective strategy in improving the students' reading competency considering the students' anxiety scale. Since anxiety has significant role in contributing students' reading competency, the teachers are expected to know the level of their students' anxiety. The other reserachers are expected to research the effect of PARTS strategy and anxiety toward other language skills (Speaking, listening, and writing). For other researchers who want to conduct research to improve the students' reading competency, it is recomendd to do further research with different reading strategy and characteristic of the students. Moreover, it is recommended to research other variables such as the location of the school (in city or in village), socio economic background of the students' parents, etc.

\section{REFERENCES}

Abu-Rabia, S. (2004). Teachers' role, learners' gender differences, and FL anxiety Among seventhgrade students studying English as a FL. Educational Psychology, 24(5), 711-721

Chang, Anna.2010. Journal : The Effect of a Timed Reading Activity on EFL Learners : speed, Comprehension, and Perceptions. Available at www.nflcr.hawaii.edu/rfl/October2010/article/chang.pdf.22 Accessed on 1st October 2012

Fraenkel, J.R., \& Wallen, N.E. (2006). How to design and evaluate research in education (6th ed.). New York: McGraw-Hill, Inc

Juniari.2005. The application of PARTS strategy to improve the Achievement of The Second Year students in Comprehending Reading Text. (A Classroom Action-Based Research Conducted at the class of Social Science 1 of SMA Negeri 4 Singaraja in the Academic year 2005/2006). Unpublished Thesis. Universitas Pendidikan Ganesha Singaraja

Marhaeni, A.A.I.N. 2007. Determinasi Beberapa Faktor Affektif yang Mempengaruhi Keberhasilan Belajar Mahasiswa Jurusan pendidikan Bahasa Inggris Universitas Pendidikan Ganesha. Unpublished Research Grand Report:Undiksha

Martin, Alex. 2007. Handling Writing Anxiety. At http://www.termpaperscorner.com/Articles/writing_Anxiety.html. Accessed on May 3rd 2013.

Mayers, Chet.1986.Teaching Students to Think Critically. Jossey-Bass Publisher.San FransiscoLondon

Na, Z. (2007). A study of high school students' English learning anxiety. Asian EFLJournal, 9(3), 2234

Newstead, Karen. 2004. Aspects of Children's Mathematics Anxiety. Journal of Educational Studies in Mathematics, Volume 30, Issue 1, Page 53-71

Seligman, L.D. \& Wuyek, L.A. (2007). Correlates of Separation Anxiety Symptoms Among FirstSemester College Students: An Exploratory Study. The Journal of Psychology. 141(2): 135146

Suzanne, Graham. 2000. Effective language learning: Positive Strategies for Advanced Level Language. University of Oxford 
Vogel, H. \& Collins, A. (2006). The relationship between test anxiety and academic performance.Journal of Abnormal and Social Psychology. 67: 523-532

Williams, Christina.2010. Comprehension Important Reading. Available at http://www.ehow.com/facts_5146900_comprehension-important-reading.html. Accessed on 1st October 2012

Waseso, M.G. 2001. Isi dan Format Jurnal Ilmiah. Makalah disajikan dalam Seminar Lokakarya Penulisan artikel dan Pengelolaan jurnal Ilmiah, Universitas Lambungmangkurat, 9-11Agustus

Zeidner. 1998. Testing situation in Test Anxiety. At http://www. Iml.uts.edu.au/assessment/students/performance.html. accessed on May 3rd 2013 